せて, 濃度1.00写真を得, ウィナースペクトルを測定し た.

〔結果〕 $60 \mathrm{kV}, 80 \mathrm{kV}, 120 \mathrm{kV}$ の順で, ウィナースペ クトルは，少しずつ高い值となった。しかしそれは，ほ んのわずかである。

〔考察〕管電圧のちがいによるウィナースペクトルを 湘定したが，あまり大きな差はなかった。粒状性は，増 感紙一フィルム系に，大きく依存しているように思われ る.

\section{9. 被写体原と粒状性の閏係}

大阪市立大学医学部附属病院中央放射線部

○渡辺晋一・畑川政勝

吉田梨影・岸本健治

〔目的〕一般に，被写体が厚い場合 X線像の画質は低 下する.これらは，コントラストの低下，散乱線の影響 等が考えられるが，今回われわれは，被写体厚が変化し た場合に，増感紙フィルム系の粒状性がどのように変化 するかを調べた。

〔方法〕管電圧を一定にし，アクリルの厚さを $0 ， 5$ ， $10,20 \mathrm{~cm}$ と変化させ,そのときのウィナースペクトルを 測定した。 また人体ファントムの水の量を変化させ視賞 的な樭察も行った。

〔結果〕被写体厚が変化してもウィナースペクトルお よび，視覚的な観察での差はわずかであった。臨床にお いて，この差はほとんど影響なく，被写体厚による粒状 性の変化は，ほとんどなかった。

\section{0. 新高鲜锐度增感紙 KO. NR の物理特性}

兵庫医科大学病院中央放射線部

○小川雅男・仲座良造・琴浦規子

鈴木 守・尾崎隆男・菅原謙三

感度を維持し鮮鋭度を向上するため開発された増感紙 $\mathrm{KO}, \mathrm{NR}$ と従来の増感紙 KS, LH-2 との物理特性の相違 について比較検討し, 増感紙一フィルム系と現像処理と のマッチングについても検討した. 結果, 増感紙 KO-250 および NR-250は KS および LH-II と比較して, 感度 は，ほぼ同一であるが鮮鋭度においては，周波数 $2 \mathrm{LP} /$ $\mathrm{mm}$ で $3 \%$ ～ $7 \%$ の向上が確認された，また，粒状性に 関しては NR-250+A では LH-2+A の組合せにみられ るような有意差はなく，現像液による依存性を示唆して いる.今後, 現像プロセス全般の影稫を加味して感材等 の選択を考えて行きたいと思う。

RI-1

座長 池本嘉範（滋賀医大）
31. データ収集プログラムによるデシタルガンマカメラ の操作性向上の検讨

奈良医大附属がんセンター

○上野山文男・安藤英次・村上悦子 大賀泰文・宇山茂樹

デジタルガンマカメラの核医学データ収集は, オペレ ータコンソールより種々の条件を入力する必要があるた め, 現在のところアナログカメラに比して操作性はやや 劣る。当院では東芝製デジタルガンマカメラ GCA-601E を使用しているが, GPL (画像処理用言語) を用いたメ ニュー方式によるデータ収集プログラムを作成，使用す ることにより，(1)検査情報の入力が不必要，(2)デー夕収 集までのコンソール操作がより単純，(3)収集しながら写 真撮影可能，(4)施設にあった収集方法のプログラムが可 能等の利点が得られたが, システムプログラムのエラー 等による若千の問題点も生じた。

32. Ring 型・同時 6 slice ECT の周発およびその性能評 価

\section{富永記念病院放射線部 \\ ○泉 幸男・柴田善行 \\ 堤 欽也・野村由明}

〔目的〕今回私たちは，島津製作所の御協力を得て， 同時 6 slice 测定の可能な Headtome II を開発し，その 性能評価を行った。

〔方法〕 ring 型および回転型 ECT について, 次の評 価を実施した。

(1)分解能…...線源の FWHM

(2)感 度……ステム感度

(3)均一性……pool data の SD 值

〔結果・考察〕分解能は, 3 slice に比し1.3倍, 回転型 に比し 2 倍あり感度は, 3 slice に比し $1 / 2$ 倍, 回転型に比 し 2 倍で, 均一性も良好で臨床上も，その有用性が墥め られた。

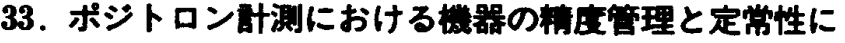
ついて一教宗

西陣病院放射線科
○堀井 均・柳生武彦・田城邦幸
岡本貴史・杉本英世・西川 亮
山岸弘志

われわれは昨年の近蟣部会において，ポジトロンCT (Headtone-III) の基本的特性について報告したが，今年 3 月よりサイクロトロンも稼動し始め，9月現在におい て約50名に ${ }^{15} \mathrm{O}$ 持続吸入法を実施し, CBF・OEF・ $\mathrm{CMRO}_{2}$ を算出してきた. ${ }^{15} \mathrm{O}$ 持続吸入法を臨床利用する 